\title{
The Lawyers' Tales: Legal Casuistry and the Spanish Golden Age Novella (Cristóbal Suárez de Figueroa, Alonso de Castillo Solórzano)
}

\author{
Mechthild Albert
}

\begin{abstract}
This contribution examines the relationship between casuistry and narrative literature in the Siglo de Oro with particular attention to legal contexts. In this respect, $E l$ pasajero (1617) by Cristóbal Suárez de Figueroa proves to be an ideal object of research, since the author, as a jurist, displays casuistic thinking, argumentation and procedure. The rather pragmatic and didactic character of this hybrid text is contrasted with novellas from the collection Huerta de Valencia (1629) by Alonso de Castillo Solórzano, whose intradiegetic storytellers are likewise characterized by their academic professions, including a lawyer.
\end{abstract}

\section{Keywords}

Casuistry - legal contexts - narrative literature - hybrid genre - novella - Cristóbal Suárez de Figueroa - El pasajero - Alonso de Castillo Solórzano - Huerta de Valencia

This contribution examines the relationship between casuistry and narrative literature in the Siglo de Oro, with particular attention to legal contexts. In view of the increasing importance of legal administrative structures during the reign of Philip II and the "legalist turn of mind" in the Baroque era, William Childers in 2011 (326) named such a focus as a desideratum for research, ${ }^{1}$ which will be addressed here within the limits of a concrete case study. In this context, the hybrid text El pasajero (1617) proves to be an ideal object of investigation, especially since the author himself, as a jurist, displays casuistical thinking, argumentation and procedure. The transdisciplinary significance of casuistry (cf. Bidwell-Steiner \& Scham, in this volume), which characterizes the mental

1 "Another topic of great interest would be the underlying commonalities between casuistry $[\ldots]$ and the unprecedented expansion of the legal system during the reign of Philip II" (Childers 326). 
habitus of Counter-Reformation Spain, is reflected in the narrative characters of the text, identified by their respective professions and their place in life. The work's hybridity, which combines humanistic dialogue and autobiographical narrative, picaresque and pastoral novel, produces varied perspectives on the different dilemmas represented. Thus a wide range of casuistical narratives unfold, occasionally in the vicissitudes of life stories, mostly in shorter forms like exempla or anecdotes, and rarely with the elaborate arrangements and dramatic intensification reminiscent of contemporaneous novels. The rather pragmatic, demonstrative and didactic character of El pasajero will be contrasted with novellas from the collection Huerta de Valencia (1629) by Alonso de Castillo Solórzano (1584-1647), whose intradiegetic storytellers are likewise characterized by their middle-class, academic professions, including that of a lawyer.

According to the high level of development of a genre reaching its peak in these years, Castillo Solórzano's novellas are very elaborate. Comparable to the comedia, they present casuistical decision-making, which, however, is not conditioned by a professional knowledge, although the intradiegetic narrators are identified by their respective professions. Rather, these conflicts seem to correspond to a primarily religiously conditioned 'casuistical mentality' of the Counter-Reformation, where only confessors are still able to distinguish between good and evil. ${ }^{2}$

In contrast, the intercalated narratives of $E l$ pasajero are rather simple stories, reminiscent of the exemplary character of the traditional cuentos described by Maxime Chevalier, and drawing on legal casuistry. The use of the latter can be explained with reference to the author as well as to the narrator figure of the Doctor (and the Maestro), who both have professional training as lawyers.

The comparison is intended not only to consider the question of the possible disciplinary influence of narrative casuistry, but also to reflect upon Karlheinz Stierle's argument for a genre development from the exemplum to the novella. The present essay's title, "The Lawyers' Tales", is an evident reference to Geoffrey Chaucer's Canterbury Tales (late 14th century) in which the "Man of Law" is both the representative of an ideal understanding of jurisprudence (comparable to the Doctor in El pasajero) and the narrator of a love story (like the lawyer Micer Hortensio in Huerta de Valencia).

As will be shown, in the two collections of novellas, two different tendencies of linking narrative and casuistry can be discerned: a more exemplary

2 See Londoño. 
juristic-secular form and a dramatically sharpened, literary form which might be associated rather with the religiously-influenced cases of conscience.

The author of El pasajero (1617) is the writer and lawyer Cristóbal Suárez de Figueroa (1571-after 1644). ${ }^{3}$ Born in Valladolid, he was awarded a doctorate in both secular and ecclesiastical law at the University of Pavia in 1594 and held various legal offices during his professional life, including auditor, abogado fiscal, contrascriptor, juez and comisario (Pelorson 394, 397). A man of letters, he was not only feared for his controversial reviews, but also known as a translator and editor of important Italian works such as Guarini's Pastor fido (1590/1602 and 16o9) and Tommaso Garzoni's encyclopedic Plaza universal (1585/1615). As a former Jesuit pupil he contributed to the spread of the order's casuistically informed ratio studiorum (Jalón 74), not least in his pastoral novel La constante Amarilis (1609) and hybrid prose text El pasajero (1617). Already in its subtitle, "Advertencias utilísimas a la vida humana," this miscelánea signals its didactic intention, whose essential vehicle is exemplary narrative. And in the prologue "Al lector" the author states: "Es mi disinio refrescar las memorias con la fuerza de avisos tan útiles, con la enseñanza de documentos tan necesarios, asestando la artillería de la razón (hecho primero alarde de bueno y malo) contra las torres de propias confianzas" (368). Structurally, the work consists of ten chapters in dialogue form, known as "Alivios", which deal with current topics of public interest, such as law and literature, ${ }^{4}$ religion and war, social change and standards of courtesy. The four protagonists of the dialogue, who meet during a journey by ship from Spain to Italy (emphasized by the genre designation "Alivio de caminantes" - see also Joan Timoneda's novella collection $E l$ sobremesa y alivio de caminantes), are characterized by their respective professions. Together they represent, on the one hand, the work's contemporaneous recipients, the readership of the "nueva nobleza" (cf. Romero-Díaz), ${ }^{5}$ and, on the other hand, two outstanding examples of casuistically-oriented careers: a "maestro en Artes y profesor de Teología", a young soldier named don Luis, the silversmith Isidro and a "Doctor of Both Laws" ("ambas Prudencias", 369), who dominates the conversations and can be identified as the author's alter ego.

3 For a detailed biography see Pelorson.

4 For these particular concerns, see Albert.

5 Suárez de Figueroa refers to this culturally significant social class as "nueva caballería" (397, 399 ) and discusses in detail its associated aspects of social mobility $(397-400)$. 
Their speeches and life accounts are part of a poetics of the exemplum ${ }^{6}$ that determines Suarez de Figueroa's understanding of the novella:

Las novelas, tomadas con el rigor que se debe, es [sic] una composición ingeniosísima cuyo ejemplo obliga a imitación o escarmiento. No ha de ser simple ni desnuda, sino mañosa y vestida de sentencias, documentos y todo lo demás que puede ministrar la prudente filosofía. (412)

In the tradition of novelistic wisdom literature, the moral teachings of the exemplum ("ejemplo") are here, as in Conde Lucanor, synthesized by a thoughtprovoking sentence or maxim. At the same time, the function of role models whether in history, literature or contemporary reality - is emphasized. In this sense the exempla serve as rhetorical arguments in terms of the docere and movere of moral development, reform and lifestyle:

Mueven los ejemplos con singular eficacia, siendo instrumentos bastantísimos para enfrenar las más desenfrenadas costumbres. Así, es justo escoger para la propia utilidad varones de ajustada conciencia y sana dotrina, por donde guiar obras, pensamientos y acciones. (642)

The rhetorical use of exempla can be identified, in particular, in the priest's professional practice, as indicated by some of the titles from the preacher's reference library, which are mentioned at the end of a long excursus on pulpit rhetoric and are particularly revealing in the semantic overlap of key terms: "Asimismo sería bien tener algunos librillos de cosas comunes, que aprovechan infinito. Tales son: Exempla virtutum et vitiorum, Similitudines Sacrae Escripturae, Summa Conciliorum, Ejemplos de Marco Marulo y semejantes" (463).

The life stories of El pasajero's four protagonists and another picaresque figure illustrate the extraordinary social mobility in this moment of the early modern period, and provide patterns of action for how the ingenium, temperament, and virtù of each individual can confront Fortuna's vicissitudes ("maravillosos altibajos"). The autobiographical accounts, therefore, provide models: existential models, as one faces the ups and downs of fate in the sense of Petrarch's Remedia (cf. Alivio IX), but also more specific models of professional careers. In this sense, the Maestro comments on the autobiographical narrative of an innkeeper as an individual and at the same time representative example:

6 For a genre history of the exemplum see von Moos. 
¡Válgame Dios! Si se pudiesen escribir los sucesos de muchas vidas, ¡qué silva de varia lección se hallaría en ellas! Maravillosos altibajos había tenido este hombre en la suya hasta entonces: labrador, soldado, religioso, tercero, valiente, bodegonero, y la última dignidad, de quién sólo se podía parar en horca ó galera. $(567)$

Such "sucesos" and "maravillosos altibajos" comprise casuistical "casos." The Maestro's professional life, ranging from medicine and jurisprudence to theology, covers the entire spectrum of academic careers in the Siglo de Oro, which are likewise significantly influenced by casuistry. As the son of a doctor, his father compelled him to continue the family tradition. However, just a few terms at the University of Alcalá made him realize his lack of affinity with this profession and change his field of study, which he justified with the Christian's freedom of will: ${ }^{2}$

Con esta declaración de mi voluntad delante, quisiera saber, profesando cristiana religión y siendo la propia conciencia el gobernalle de cualquier hombre que desea salvación, con qué seguridad de la mía pudiera engolfarme en el grande océano de lo propuesto. ¿Yo ensayarme primero en los pobres? ¿Yo cometer indignos robos en la miseria de los mendigos? (450)

His father kept urging him to practice the lucrative profession, which provides an opportunity for a satirical reading of the estates, since he claims it is enough to master "alguna cantidad de aforismos y brocárdicos", "que en la ciencia médica sirven de lugares comunes", because "esta vida es toda artificio" (449). Yet, the son proves his moral integrity by his rejection of the medical profession, invoking his conscience. As an alternative, he now strives for the socio-politically significant career of "Leyes y Cánones" - "profesión noble, ilustre, vida y alma de las ciudades, conservación del mundo" (451) -, which at the same time signifies a gain in prestige. Just as the father yields to the son's rosy visions of a future with a bright career in the legal profession, "donde, en entrando, lloverán tan grandes mercedes, que, no sólo será fácil colocarme en

7 The definition by Antonio Fernández Cano is informative in the present context: "Casuística procede de la palabra latina casus: evento imprevisto, azaroso, fatídico, sin precedentes. En terminología legal, casus significa: hecho preciso, real o supuesto." (49o).

8 Childers emphasizes this with reference to the probabilism of a Francisco Suárez: "[...] in doubtful cases a confessor must respect penitents' unalienable possession of free will (liberum arbitrium)" (318). At the same time, the question of freedom of will in conjunction with predestination and Grace represents an initial starting point for questioning probabilism (cf. Fernández Cano 502). 
perpetua silla occidental o antártica, sino en las mejores audiencias ó chancillerías españolas" (451), he passes away, leaving the student to an uncertain fate, "lleno de irresolución y ambigüedad" (451). Faced with economic hardship, he decides, without the slightest vocation, to study theology, to which he devotes himself with great zeal - "con el ardor que me infundía el menester" (451) - in expectation of social and financial security: "por el seguro premio que suele alcanzar su eminencia en las oposiciones así de cátedras como de dignidades" (451). As an unqualified but influential competitor blocks his further advancement, - he decides personally to resolve the situation in Rome, the center of religious power - "cabeza de la Iglesia [...] y mar profundo, donde las redes de letras y méritos sacan copioso número de diversas remuneraciones, pescados de segura duración" (452). It is this circumstance which results in his status as one of the 'passengers'.

Complementary to the figure of the Maestro is the Doctor, alter ego of the author and protagonist of the present dialogues. As the quintessential "pasajero" he represents the homo viator, an allegory of the impermanence of the conditio humana; on the other hand he embodies the concrete historical situation of an individual in the interplay of jurisprudence and literature, between both shores of the Spanish Mediterranean. ${ }^{9}$ The Doctor's career embodies the connection between science and experience, theory and practice, since he is a graduate of the "facultad de ambas Prudencias, con título de doctor, aunque más docto en experiencia y comunicación de naciones" (xv).

The interaction of theory and practice refers to the dialectic of induction and deduction, which is constitutive for casuistry as a "practical application of moral principles to specific cases" (Childers 317 ) and the disciplines it shapes. ${ }^{10}$ This is also underlined by a remark of the young soldier don Luis, the representative of vita activa, who points to the need for complementing scholarly writing with "uso," so that people, thanks to these examples, can immediately apply their knowledge as captains to steer through the perils of life:

Sábese ser el uso, casi en todo, el maestro más cierto y mejor; ni hay cosa tan digna y loable como beneficiar a otros con ser instrumento de sus bienes y luz de sus yerros. Igualo este fruto al de los escritos, en cuya virtud muchas cosas pasadas que por ningún modo podrían haber llegado a nuestra noticia, mirándolas como en espejo juntas y recogiendo dellas lo que nos conviene, amaestrados con ejemplos osamos con más seguridad,

$9 \quad$ See "La double signification du titre" (Pelorson 410-412).

10 On casuistry as "ciencia aplicada que investigaba hechos particulares aplicando principios preestablecidos con el objeto de obtener normas que pudiesen gobernar la acción", see Fernández Cano 491-492. 
como pilotos práticos, entrar en los no antes sulcados piélagos o caminadas sendas de la vida. (373)

When it comes to the literary ambitions of the 'passengers', the lawyer, el Doctor, wants to entrust the soldier Don Luis with the writing of exemplary historical episodes precisely because of his practical experience of life, since historiography is the discipline in which theory, science and pragmatics, lawfulness and individual fates form an ideal combination:

Doctor. [...] la más digna de todas las lecciones viene a ser la de Historia, por aprovechar con la narración de públicos negocios o particulares acciones, no comunes, sino singulares y famosas. Por eso concluyen comúnmente ser la misma testimonio de los tiempos, luz de la verdad, vida de la memoria, maestra de la vida y mensajera de la antigüedad. (413)

With regard to this casuistical understanding of history as magistra vitae, don Luis' alleged deficit, namely the lack of relevant (humanistic) scholarship, proves to be an advantage that enables him to apply historical lessons of both representations of exemplary "casos" in the service of truth:

DON LUIS. ¿Por qué camino, según eso, pudiera yo sacar a luz historia acertada, si carezco de erudición, de inteligencia y prática para narrar no solamente los hechos, sino rastrear también la razón con que se hicieron, y juntamente los consejos y motivos que pudieron intervenir en los casos? Sin esto, son menester papeles; que escribir sin comprobar antes es propio de fábula que historia. (413)

In doing so, the author makes it clear that historiography is not only concerned with the facts of the illustrative "casos" in question, but also with their circumstantial contextualization, a procedure clearly marked by casuistry, as expressed in Azpilcueta's hexameter "quien, que, donde, con que, como, quando" (Bidwell-Steiner \& Scham, in this volume).

In Suárez de Figueroa's work, we find repeated moralistic analysis of human characteristics and behavior, for example, in the distinction between two forms of ignorance (590), friendship ("amistad de costumbre" vs. "amistad de razón", 470), and wrath ("ira virtuosa" vs. "vengativos y coléricos", 6oo-601). The dialogue about this vice between the Doctor and the Maestro is particularly 
revealing with regard to the argumentative use of exempla and casus, including their corresponding maxims: while the theologian refers back to historical examples provided by philosophical or religious authorities, apparently taken from Cesare Rao's Invettive, orationi, discorsi [...], (109v-116r), the jurist reports a contemporaneous event which he heard from an eyewitness, but also concludes with a quotation from Seneca. In both cases the narration is coupled with a mnemonic. The starting point is the fundamental meaningfulness of natural affect, which is compared to the steel of a blade, ${ }^{11}$ whose morally good or reprehensible use, in the casuistical sense, depends on the goal, purpose and context:

Doctor. [...] Es a propósito enojarse sólo consigo mismo de las cosas mal hechas; que con este fin la Naturaleza, que ninguna cosa hizo ni ordenó sin causa, mezcló entre nosotros este afecto. De suerte que, afrentado cualquiera de lo que hubiere cometido contra el Criador y su criatura, se emiende y corrija con este ardor, corrido de lo pasado. En tales casos es la ira virtuosa, justa y alabada, como efeto natural, y así, santo y perfeto el enojo en quien preceden estas causas. Hállase puesta (dice un curioso) la ira en los humanos entendimientos como el acero en la puntay corte del cuchillo, para que corte donde y cuando sea menester. (6oo)

Wrath is an emotion that plays a central role, in particular, in the medieval mirrors for princes, since a ruler is only capable of ruling justly if he knows how to control his affects. In this tradition, which usually takes the form of doctrinal dialogues between rulers and philosophers, the Maestro contributes two "ejemplos admirables" to the discussion over this vice, "[que] suelen ser comunes desta materia" (6oo). He begins with the famous advice of Poseidonius to Emperor Augustus, who is said to have asked the philosopher for "alguna sentencia digna de eterna memoria" before his return to Greece: ${ }^{12}$

Cuando te veas (respondió) vencido del furor, pasión digna de ser aborrecida de cualquier hombre, principalmente de príncipes, que han de ser señores, no siervos, antes de decir o hacer alguna cosa recita todas las letras del abecé. (6oo)

\footnotetext{
11 While Rao (114r) attributes this observation to a "celebre \& approvato autore Catolico", Suárez de Figueroa (6oo) attenuates the reference to the expression "dice un curioso." 
The second example is St. Ambrose's rebuke to Emperor Theodosius after a massacre driven by wrath. Ambrose denied the ruler access to the Cathedral of Milan and urged him to repent, since, apart from the act of "inhumanidad," he had lacked the fear of God, the supreme virtue of a ruler, who is subject to the will of God just as the most inferior of his subjects. The wrath of God is also recalled, being unleashed by sinful humanity, but nevertheless appeased by righteous individuals (like Noah or Lot): "No olvides que, así como Nuestro Señor se aíra, se embravece y enoja por la culpa, también se aplaca, se amansa y humilla por la penitencia" (6o1). The ruler obeys the admonition of the churchman - "Vuélvete a tu palacio, y alli, con verdadera contrición, entre ceniza y silicio ejercita los actos dignos de penitencia" (6oo-6o1) -, which may have been understood by contemporaneous readers in terms of Counter-Reformational piety and penitential practice. ${ }^{13}$ When the Emperor visits the Cathedral at Christmas, after months of retreat, the Bishop of Milan grants him absolution on the condition that a new law be enacted with the aim of preventing death sentences passed under the influence of wrath (6o1).

In these two historical exempla, the recommended reflection periods of, respectively, seconds and days for controlling an outburst of rage are praised by the Doctor as "dos remedios para domar, señorear y vencer el más colérico accidente que pueda mover guerra a la razón, como su capital enemigo" (6o1). At the same time, he establishes a topical connection by denouncing duels out of offended pride as a new form of excessive, destructive rage. The "caballeretes de ahora" respond to the slightest insult like a viper in order to take revenge by force of arms according to their code of honor: "Juzgan de ánimo vil no vengarse de toda intención, cuanto más de cualquier obra que se enderece a su agravio" (6o1). In contrast, he demands Christian forgiveness ("perdonar injurias") as an exemplary behavior, which he illustrates with an anecdote that took place in Trujillo and that he learned from an eyewitness, thus verifying its truth. The incident combines the specific with the general, the individual behavior with the moral norm:

13 In a different passage the Maestro also mentions the Grace of God towards the repentant sinner and the postponement of his wrath: "Esta confianza, pues, no ha de perder el bueno que entre muchos malos anda en un mismo navío por la mar. Debe entender que, aplacada su justa indignación, perdonará Dios a los de mala conciencia que con él van, dándoles tiempo de penitencia y emienda (cosa que está obligado a pedir el que menos pecador se sintiere), y que, dado que por su perseverancia en el mal quiera Dios castigarlos, dará evasión de aquel peligro a los buenos, reservando la ejecución de su ira para otro tiempo" (481-482). 
Contome [sic], como testigo de vista, un caballero de Trujillo, nieto del memorable García de Paredes, un caso sucedido en aquella ciudad, dignísimo de quedar grabado con letras de oro para ser en todas edades ejemplo de vengativos y coléricos. (6o1)

The everyday case ("como es costumbre") begins with a dispute at a ball game between aristocratic figures, which escalates dramatically as a servant of the opposing side insists on the right of his master, whereupon the offended person draws his sword. However, at the last moment, the weapon already on the chest of the opponent, he pauses to renounce the bloodshed in Christ's name:

Asiole el agraviado de un brazo, y desenvainando con notable presteza la daga, le arrimó la punta al pecho, diciendo al querer ejecutar: Perdónote por Jesucristo; que así lo manda su Majestad. Con esto dejó libre al asido $\mathrm{y}$ atónitos a los circunstantes, por ver tan grande valor y generosidad de ánimo, ya que en ninguna otra cosa se conoce y manifiesta tan de veras como en perdonar las injurias. (6o1)

With this position, Suárez de Figueroa takes sides in the "diálogo de sordos que se mantuvo a lo largo del Siglo de Oro entre impugnadores y defensores de la ley del duelo" (Chauchadis 108), ${ }^{14}$ in accordance with the prohibition of duels issued by the Council of Trent under threat of excommunication. ${ }^{15}$ The renunciation of violence also illustrates in many ways the poetological affinity between anecdote, case, novella and drama. The unique and at the same time generalizable nature of this extraordinary action as the epitome of courage and generosity ("tan grande valor y generosidad de ánimo") is underlined by the presence of an audience and its reaction ("atónitos"). The episode combines the exemplary, dramatic narrative with an aphorism, whereby this moral quintessence, the act of grace, refers simultaneously to the two highest authorities, the secular and the metaphysical, which, within the framework of the

14 In addition to pragmatic and moralistic texts, Chauchadis uses the comedia in particular as an example of the highly differentiated casuistry of "casos del duelo" or "casos de honra". Evidence of Christian renunciation of violence in situations of "desafío" can be found on pages $86,87,97$ f., 102 .

15 For more on Suárez de Figueroa's opposition to duelling, see also the corresponding chapter "Discurso LXX. De los duelos y desafíos por carteles y padrinos de campo" in his Plaza universal de todas las ciencias, whose conclusion states: "Estas son las leyes de la honra del mundo, a quien dan semejante nombre los mal considerados: con que se da fin a la inicua materia del duelo, puesto aquí por curiosidad, y ya en nuestros tiempos reducido como merece su total ruina: pues casi en ninguna Provincia o ciudad es admitido, ni tiene lugar" (553). 
Catholic monarchy of the Siglo de Oro, mutually reinforce each other. ${ }^{16}$ The contemporaneous contribution from the jurist's field of experience is finally concluded, once again, by a scholarly quotation from Seneca: "Quien déstas [i.e. injurias] se acuerda (dice Séneca) pierde la virtud de la memoria” (6o1).

The relationship between ruler and philosopher or advisor known from the mirrors for princes ${ }^{17}$ is prevalent in the Siglo de Oro. Yet, in accordance with the salient function that jurisprudence - alongside religion - plays as the leading discipline of the Habsburg Empire, the role of advisor is increasingly taken over by jurists. The "rey sabio" requires the "servicio de los sabios" in the interest of state affairs, which guarantees the combination of "sabiduría" and "virtud," theory and practice, "siendo de contino compañeros en el gobierno la ciencia y prática" (392). The political system therefore needs lawyers as advisors in cases of doubt which entail casuistical thinking and action:18

[...] es importantísima al que administrare justicia la prudencia, guía y madre de todo lo bueno, y derecha razón de las cosas agibles, siendo general en todos la necesidad de la ajena. Requiérese, sobre todo, el consejo, que es bien pensada razón de lo que se debe hacer, buen aviso que se toma sobre casos dudosos. (392)

With regard to co-responsibility in government, the lawyer Suárez de Figueroa sketches an ideal image of the highest judges as the right hand of the "sabios gobernadores".19 As representatives of the interests of the people, they need to show integrity in every respect ("intención, sabiduría y limpieza", 516) and be incorruptible, "sujetos dignísimos de toda recomendación, por el celo en la justicia, por la asistencia en las causas, por la entereza en el sentenciar" (516). With expertise and knowledge, they decide cases of greatest importance: "Determínanse en sus salas casos gravísimos, en rentas cuantiosos, en dignidad

16 The amalgamation of politics and religion can also be seen, for example, in the fact that Christ's obedience to his Father is interpreted in the political sense as the virtue of the subjects in relation to the King, for the benefit of the res publica (613).

17 For more on mirrors for princes during the Siglo de Oro see García Fernández.

18 Unfortunately, the complex context of Machiavellianism in Spain cannot be discussed here.

19 See also the corresponding chapter in Plaza universal: Discurso V: "De los Doctores de Leyes, o Jurisconsultos." 
sublimes, sin que alguno pueda asegurar la sentencia en más que su derecho" (516). As guarantors of the welfare of the res publica, he compares them to the "antiguos senadores de Roma, los verdaderos padres de la patria" (516). God-fearing ("temeroso de Dios", 515), they are to strive for the middle course between "flojedad y blandura" (515) on the one hand; "rigor" (519) and "severidad atroz y endurecida" (515) on the other hand, and at the same time they are obliged to the people and to justice: "La equidad del varón ha de consistir en amar a los hombres por la justicia; no posponer la justicia por los hombres" (515). From this ideal profile he discriminates the lower ranks of the judicial administration, characterizing them in accordance with the time's typical scolding of jurists as uneducated, incompetent, and corrupt, as well as young judges, who are marked by a particular arrogance, toughness and mercilessness, so that their term of service must be kept to a minimum: ${ }^{20}$

No hay furia tan tremenda como un juez primerizo, uno que desde el mendigado estudio se trasladó a la vanagloria del mando, a la ociosidad del gobierno, donde anhela por las bolsas de todos, donde muere por sembrar fuego en su distrito, desnudo de piedad, de consideración, sin Dios, sin ley ni miedo, mientras duran los tres años de su alcaldía o tenientazgo. (517)

To reinforce this stark portrait, the Doctor describes a case that he had witnessed shortly before. It involves a nocturnal house search with the aim of proving that an unsuspecting tailor had an adulterous relationship three years prior to his wife's death. The anecdote not only serves as evidence for the inhumane procedure of inexperienced judges, but the outrageous accusation involves casuistry regarding love and marriage. ${ }^{21}$ Comparable to a confessor, the representative of the law himself uses a casuistical questioning technique

20 In connection with questions of administration and legal practice, the Doctor is of the opinion that important legal positions should not be filled by persons of short stature, as they do not exude authority; to substantiate this, he refers to a precedent that is said to have occurred under the reign of Philip II (524-525).

21 Cf. Del Río Parra; for the following example particularly pages 154-155. An awareness of the corresponding categories of guilt and innocence is also evident in the autobiographical account of a picaresque innkeeper, who, after the victory of the "apetito" over the "razón", once again seeks out his casual lover, "aunque pecadora, hembra de nobles respetos", with the ostensible intention of marrying her one day, by that calming his conscience, since he thereby almost fulfills the excusable factual situation of the "matrimonio secreto": "Tenía yo propósito de volver aquel lecho, entonces sentina de maldades, en lo porvenir lícito y conyugal, como dicen los polidos, y así, no me desasosegaba mucho la conciencia" (559). 
to elicit the desired confession from the accused. This corresponds (with the exception of the last point) to the procedure described by Fernández Cano (492) - Descripción del caso, Cuestiones sobre el caso, Resolución de cuestiones:

Llegó una noche a casa de un sastre un teniente de cierta villa. Los galfarrones que le acompañaban comenzaron a derribar las puertas con furia de golpes. Levantose el hombre soñoliento, y preguntando quién llamaba a tal hora (que era casi la de las doce), respondieron abriese a la justicia. Bajó desnudo y turbado, y subiendo el tal ministro hasta su cama, halló en ella a su mujer y a una niña de cuatro años, habida en cierta flaqueza. Con aquel endiosamiento que suele tener un juez mozo (que no era viejo éste), le fue haciendo preguntas, enderezadas al examen de su conciencia: qué oficio tenía, quién era aquella mujer, y si era su hija aquella criatura. Fue respondiendo a todo como convenía, y, sobre todo, confesó ser padre de la muchacha. Díjosele si era también hija de su mujer; declaró que de otra persona, difunta tres años había. Esto bastó para decirle que se vistiese y para enviarle a la cárcel con título de amancebado con la fallecida. Por ser tan tarde, no hicieron más que meterle dentro y dejarle a su albedrío. $(517-518)$

The unfortunate defendant has to spend the night in jail, where the torture rack of another victim of justice serves as a place to sleep. However, the Doctor does not speak and act exclusively as a representative of the law and the legal system, but also as a defendant. His life story contains some picaresque episodes in which he is - rightly or wrongly - persecuted by Justice, allowing the reader to perceive the judicial system from two different perspectives. When the protagonist is accused of a homicide, a merciful person visits him in prison and questions him in a way similar to the casuistical manner in which the examining magistrate questions the tailor. Based on the practice of the examination of conscience, the two lead a kind of confessional dialogue, which in the midst of "culpas," through "perturbación," "tribulación" and "confusión" is intended to lead to the truth, whereby in the present case it is not the guilt but rather the innocence of the wrongfully accused that comes to light:

DOCTOR. Entre los que acompañaron al corregidor se halló uno del lugar, que me conocía. Lastimóle mi prisión; mas como era el caso de voz tan importante, no tuvo ánimo para decirme una palabra ni para interceder con el juez por ningún camino. Quiso, con todo, cumplir con la de misericordia en visitar los presos. Saludome, y fuese cortésmente compadeciendo de mi infortunio. Luego procuró tocar con la mano la que sirve 
por mil testigos: la conciencia. ¿Siente vuestra merced (me dijo) haber cometido cosa por donde le hayan traído aquí justamente? Respondí: No, por cierto; que, aunque impaciente y mal sufrido, ni he dado ni me han dado ocasión de pendenciar ni herir. jBien cuadra eso (prosiguió) con el título de su prisión! Pues sepa que ha procedido de haber un ventor denunciado que mató a un hombre en la Corte. Es mentira (repliqué); mas quizá Dios permite padezca mi ánimo esta perturbación por otras culpas; y así, en ella no perderé sufrimiento y paciencia. Huélgome, con todo, de saber nazca semejante tribulación de esa voz, por haberla de hacer presto mentirosa la verdad. Aunque aflige, no come este lugar a los hombres; haranse las diligencias para salir dél con brevedad. En tanto, quisiera saber quién aplicó a mi inocencia este testimonio. Un arriero (respondió enternecido el oyente) fue quien, al pasar por la plaza, lo dijo al corregidor. (538)

In the course of his adventurous escape through Andalusia, the Doctor not only makes acquaintance with the power of law. In Granada he also witnesses a tragic love story centering on Jacinta, whose name should go down in history as an example of excessive love: “¡Oh mujer dignísima de cualquier loor, cuán de veras amabas, cuán altamente engrandecías los triunfos de Amor! Oh nombre merecedor de ser grabado en bronces inmortales, para ejemplo de venideros siglos!" (577). As proof that "se puede morir por mucho amor," the Doctor places her story among a series of countless illustrious predecessors ("ejemplos sin número"), such as the Greek youth Eliano or the medieval "amantes de Teruel," to whom Don Luis adds the lovers Don Pedro of Aragón and Lisa (578), known from Boccaccio's Decameron $(\mathrm{x}, 7)$. The literary character of this episode is not only demonstrated by this implicit reference; the tragic "caso[.] de amor" (577) also fully displays the thematic stereotypes, narrative strategies and rhetorical procedures of the novela pastoril, including the genre's love casuistry. ${ }^{22}$

Alonso de Castillo Solórzano: Huerta de Valencia (1629)

A comparative glimpse at Alonso de Castillo Solórzano's (1584-1647) collection Huerta de Valencia (1629) demonstrates that, in contrast to El pasajero, the

22 See also "infelicísimo caso" (578) and "lamentable caso" (581); cf. Sánchez Jiménez. 
relationship between frame and embedded narratives is reversed: the novellas take center stage, while the frame story is reduced to the usual minimum for Spanish authors following Boccaccio. In this sense, the casuistically tinged debates on the moral-philosophical aspects of the respective novella plot are also missing. In the "huerta de Valencia" five bourgeois narrators gather during Easter on their estates (alcarrias). The five intradiegetic narrators who form a homosocial masculine group in the spirit of an academy are presented in hierarchical order with name, age and profession as representatives of an otium cum litteris. This entails an almost complete tableau of contemporary scientific disciplines, including medicine, law and theology as well as philosophy and history, classical philology and rhetoric.

While Don Guillén, a young, musically gifted student of "filosofía y letras", organizes the performance of a play on the fifth and last day of the 'academy', the remaining four characters, as hosts of each day, also act as narrators of the corresponding novels, to which the guests also contribute lyrical compositions. In the introductory setting, the actors are presented in order of appearance, such as the humanistically educated Don Leonardo, the protagonist of the first day:

Don Leonardo (que era el de más edad) había estudiado, hasta saber con perfección la lengua Latina, y la Rethorica, y de Historia lo bastante para hablar en cualquier conversación con seguridad de ser bien oído, y no censurado. Hacía versos con cuidado, no con afectación.

Huerta, Introduction, s.p.

As the senior member of the group, he tells the most revealing story in terms of casuistry, "El amor por la piedad," which focuses on a young nobleman from Burgos who is used as an example to explain issues regarding the concepts of guilt and innocence. He is wrongly accused of the abuse of a noblewoman and the murder of a stranger, both representing cases of great moral significance. The second day is hosted by the physician and philosopher Doctor Eusebio, who in his spare time honors the Muses: "También daba tal vez feudo a las Musas en los ratos que descansaba de sus estudios" (Huerta, Introducción, s.p.). The novella he presents, "El soberbio castigado," is a rather bold and simple example from the realm of politics, contrasting a righteous counselor and a morally dubious "privado" who, due to uncontrolled emotions (here more envy than wrath), becomes a traitor and is finally executed as a cautionary example. This is followed by the story of the young theologian Laurencio, who, with "El defensor contra sí", presents a highly dramatic crime story about love and honor, which raises a whole series of casuistical problems but ends on a happy note with an anagnorisis between father and son. The last novella is presented 
by the host of the fourth day, the "letrado" or lawyer Hortensio, who is characterized as follows:

Micer Hortensio era Jurista, y el más consumado sujeto en aquella ciencia, profesada de muchos, y bien usada de pocos, [...]. Era mozo este prudente Letrado, y en las vacaciones de su estudiosa y continua ocupación imprecaba tal vez al Délfico Planeta auxiliador de la poética congregación del Parnaso.

Huerta, Introduction, s.p.

His story "La duquesa de Mantua" is a novela cortesana (cf. Palomo) with both amorous and political plot elements, in which numerous characteristic motifs of literary casuistry and its associated moralistic reflection come together (cf. Kallendorf 2004): the challenge posed by coincidences, misunderstandings and twists and turns of destiny, the unknown or concealed identity, the typical baroque dialectic of engaño and desengaño, the conflict between love and social hierarchy, and the significance of jealousy for igniting passion in various love-triangle scenarios.

As narratives texts of a fictional genre, which shows close parallels to the comedia, the novellas of the Huerta frequently present elements which Kallendorf (2007) considers to be indicators of casuistical procedures, such as the dramatic monologue in moments of decision, the dramatization of typical cases of conscience with the corresponding vocabulary of moral confusion, as well as questions of guilt and inextricable situations of double bind. Such a situation of conflict in the form of a "choice between two viable but mutually exclusive options" (Kallendorf 2007:347) is at the center of the novella "El amor por la piedad." After courting and promising to marry Leonarda, the protagonist Fernando arrives at her house for their first nocturnal meeting. However, Leonarda's maid had mistakenly ("por yerro", 64) allowed another man into the house, who decides to take advantage of the situation ("gozar la ocasión", 64). Fernando becomes aware of the prior presence of an unknown rival when, during the course of the same night, he shares the bed with his lover, but Leonarda does not realize that she has been deceived. The protagonist now faces the almost hopeless choice between revealing to his lover that she has been seriously misled and that her honor has been violated - without being able to name the perpetrator - or remaining at her side as the betrayed fiancée. When Leonarda demands marriage and her cousin tries to take revenge, Fernando flees from Burgos to Valladolid, where he falls in love with another lady, named Estefanía. She stands by him when he is wrongly accused of murder, again due to a misunderstanding, and becomes his official lover as soon as the judicial error is resolved in his favor. The situation escalates once again when Leonarda 
and Estefanía meet as rivals in Madrid. This time, a clergyman acts as a Deus ex machina, being able to resolve the entangled case after having taken the confession of a dying man who admitted to Leonarda's abuse. In the categories of clerical casuistry based on Aristotle, this crime is a deliberate act ("voluntaria"), but on the part of the woman it is an act not deliberately committed, due to ignorance ("no voluntaria", "por ignorancia"). ${ }^{23}$ After the truth has come to light through confession, the solution of an individual "caso de conciencia" opens the path for a happy ending with a double wedding.

The protagonist of the novella "La duquesa de Mantua," told by the lawyer Eusebio, is an enigmatic young man who almost kills a duchess while hunting, whereupon the two freeze in "suspension" (203), marking the beginning of a complicated love story. Already the contradictory social signals conveyed by his clothes - a peasant cape over richly embroidered trousers - spark curiosity and "sospecha" (209) and point to a "secreto" (216). The figure of the "forastero" (208) is in this respect an "enigma" (204), which is not resolved even by his alleged life story; he remains "Fabio el encubierto" $(237,238)$. Thus the casuistical tension between (dis)simulation and its revelation, i.e. between engaño and desengaño, in conjunction with the search for the true identity, becomes the novella's leitmotif. Only at the end, through the adoptive brother's account and the public anagnorisis between father and son, it is revealed that Fabio is actually Rugero, the Duke of Ferrara's illegitimate son. Despite various indications of his prominent origin, such as his mastery of rhetoric, poetry and singing, his politeness and gallantry, his sporting and military excellence, in which the performative character of subjectivity is also manifested, ${ }^{24}$ the truth remains unknown to him until that moment.

Through the final desengaño regarding the protagonist's social identity, the love story can still have a happy ending. From the first moment Fabio had fallen in love with the duchess, "un imposible" (207) because of their social differences, he undergoes various trials and tribulations in the hope of gaining more "dignidad" (237). For both protagonists, the hierarchical divide leads to an amalgamation of social hierarchy, politics, and affects, giving rise to numerous moments of casuistical self-reflection. At first, the duchess grants him her favor only as a ruler, appointing the talented poet and singer as her court musician. This is a deeply hurtful insult to the mysterious stranger and lover, which makes him fall ill (230 s.). The topos of the "amor hereos" (cf. 224) is further exacerbated by the social divide and the despair over the fact that "su

\footnotetext{
23 Cf. Kallendorf 2004: 350 with reference to Francisco Cascales: Tablas poéticas (1617).

24 Cf. Childers 319: "The quintessentially Baroque problematic of the performative nature of the self."
} 
desigualdad" (224) drives him almost insane ("tener por loco", 224). Therefore, he leaves the court of Mantua as a means of protecting himself and, through his absence, luring his beloved out of her reservations. In this peripheral position he finds out about a conspiracy by the Duke of Modena, who wants to kidnap the Duchess of Mantua for rejecting his love. Fabio wants to thwart the conspiracy against his beloved and, through his reflections ("considerando lo que avía de hazer en este caso", 242), he weighs the various options for action with their respective political and private implications in order to develop a promising "estratagema" in the face of the "duda", presenting a prime example of casuistical reflection upon one's own actions and their possible consequences, effectively "micromanaging their moral decisions" (Childers 325). His plan ("su traça", 245) works: the kidnapping of Duchess Camila is prevented, the traitor is executed, and the equally disappointed and angry admirer is put out of action and morally condemned by Camila's dialogue, since he wanted to gain her love by force (253).

By this point, the duchess's feelings for Fabio have changed as a result of the interplay of various emotional and rational factors that are characteristic of love casuistry. Her jealousy towards her lady-in-waiting, whose feelings for Fabio are only too obvious $(224 ; 231)$, her own claim to possession of the gallant stranger (238), coupled with remorse, having offended him by his appointment as court musician; and the regret over his absence (235) generate ambivalences and inner conflicts (227), which Camila tries to weigh rationally, but which nevertheless drive her into melancholy (239). Only the revelation of Fabio's true identity establishes equality of rank between the lovers and thus ends the conflicts between passion and class consciousness. With her happiness in love, Camila proves to be both a strong and mild ruler, since she will pardon the Duke of Mantua - after the conspiracy, his temporary imprisonment and a military campaign - marrying him to the illegitimate daughter of the Duke of Ferrara.

\section{Conclusion}

A summarizing comparison of both texts with regard to the narrative use of casuistry allows to conclude that the lawyer Cristóbal Suárez de Figueroa presents a strongly pragmatic miscelánea in dialogue form interspersed with stories of variable length. In addition to the extensive (pseudo)autobiographical narratives, there are mainly concise anecdotal exempla, which often serve as moral doctrine or illustrative argumentation. Although Suárez de Figueroa draws on the old concepts of exemplum and aphorism, he tells mainly 
contemporaneous cases from Habsburg Spain, while ancient exempla are only quoted as an element of encyclopedic erudition, probably assuming that they are familiar to the educated reader. By referring to "ejemplo" and "sentencia" in his definition of the novella, he proves to be conservative, using what Karlheinz Stierle called genre molds $(581-595))^{25}$ The fact that El pasajero is dominated by exemplary narrative is probably owing to the professional and epistemological background of the Letrado-author and his dominant narrative figures the lawyer and the theologian, each of which is associated with their specific use of exempla and case.

Castillo Solórzano's Huerta de Valencia, on the other hand, is clearly a collection of novellas in the modern sense, following Boccaccio's example. Fictionality allows the triumph of "contingency" (Stierle 582) through the work of "literary coincidence" (Köhler 1973) and a concatenation of complex cases of conscience. The extraordinary entanglements of these novellas make it clear that fiction is in no way inferior to the "outrageous and improbable" cases discussed in the summae (Childers 323), thus adding even more opportunities to see casuistry "as a totalizing discourse that attempts an exhaustive treatment of all possible moral situations" (Childers 325). Author, characters and recipients refer to casuistical patterns of thought that are used independently of specific professional practice. The narrators are academically educated citizens assigned to certain professional groups which are, however, irrelevant for the subject matter and argumentation of the respective novels. The Latin scholar, for example, tells an entanglement of guilt and innocence, while the lawyer tells a courtly love story. The ultimate goal of both novellas, however, is the search for truth beyond "apariencias", "disimulación" and "engaño." The social spectrum of narrative figures and actors proves not least of all that "a probabilistic casuistry was the most adaptable to different professions, social classes, and political circumstances" (Childers 318 ). In the novella "emancipated' from the exemplum, it is irrelevant whether a lawyer or a theologian narrates a complex fictional case - all of them testify equally to casuistry as a mental habitus. ${ }^{26}$

25 A different historical perspective, from Boccaccio to Chaucer, is offered by Jan Söffner (292), who - despite decisive differences - states that in both cases the staging is "different and competing hermeneutics", "which ensure that his casuistry does not lead to general theorems". To what extent this finding can also be applied to the authors and texts on which this study is based would have to be examined in light of the Counter-Reformation and Baroque periods.

26 At this point I would like to thank Ulrike Becker for her important suggestions and advice and Álvaro Arango Vallejo for the translation of this essay into English. 


\section{Works Cited}

Albert, Mechthild. "Letrados y literatos en la novelística áurea - El pasajero de Cristóbal Suárez de Figueroa." La autoridad de los saberes: El letrado. dir. Christoph Strosetzki, coord. Blanca Santos de la Morena, Hipogrifo 9.2, 2021: 149-161.

Becker, Ulrike. "Saberes y género narrativo en La constante Amarilis de Cristóbal Suárez de Figueroa." Saberes (in)útiles: el enciclopedismo literario áureo entre acumulación y aplicación. Eds. Mechthild Albert and Ulrike Becker. Madrid/Frankfurt am Main: Iberoamericana/Vervuert (Biblioteca Áurea Hispánica), 2016: 181-200.

Bradbury, Jonathan. The Miscellany of the Spanish Golden Age: a Literature of Fragments. London/New York: Routledge, 2017.

Chauchadis, Claude. “Libro y leyes del duelo en el Siglo de Oro." Criticón 39 (1987): 77-113.

Chevalier, Maxime. Cuentecillos tradicionales en la España del Siglo de Oro. Madrid: Gredos, 1975 .

Childers, William. "Hispanic Casuistry Studies: Room to Grow." Hispanic Review 79.2 (2011): 317-326.

Del Río Parra, Elena. "Sobre el alma: matrimonio, confesión y casuística en torno a $E l$ Burlador de Sevilla." Revista de literatura 68. 135 (2006): 151-171.

Fernández Cano, Antonio. "La casuística: Un ensayo histórico-metodológico en busca de los antecedentes del estudio de caso." Arbor CLXXI.675 (marzo 2002):489-511.

García Fernández, Eduardo. El discurso sobre la virtud política en los espejos de príncipes de los Austrias. Valentía y templanza en la teoría política entre el Renacimiento y el Barroco. Universidad de León, PhD dissertation, 2019, https://buleria.unileon .es/bitstream/handle/10612/11599/Teis\%2oEduardo\%2oFern\%C $\%$ \%Andez\%2o Garc\% $\%$ \%ADa.pdf?sequence $=1$ \& isAllowed $=y$ (Accessed 31.08.2O2O).

Jalón, Mauricio. "El 'orden de las ciencias' en el sigloXVI y la Plaza Universal." Península. Revista de Estudios Ibéricos 5 (2008): 65-82.

Kallendorf, Hilaire. “¿Qué he de hacer”? The comedia as Casuistry.” Romanic Review, 95.3 (2004): 374-359.

Kallendorf, Hilaire. Conscience on Stage: The Comedia as Casuistry in Early Modern Spain. Toronto: University of Toronto Press, 2007.

Köhler, Erich. Der literarische Zufall, das Mögliche und die Notwendigkeit. München: Fink, 1973 .

Londoño, Marcela. "El pecado de superstición en los confesionarios modernos." Pecados profesionales en el Renacimiento. Eds. Emilio Blanco and Mechthild Albert. Wien/Berlin/New York: Peter Lang, 2021 (2022: 97-116).

Moos, Peter von. Geschichte als Topik. Das rhetorische Exemplum von der Antike zur Neuzeit und die historiae im Policraticus'Johanns von Salisbury. Hildesheim/Zürich/ New York: Georg Olms, 1988. 
Palomo, Pilar. La novela cortesana. Forma y estructura. Madrid: Planeta, 1976.

Pelorson, Jean-Marc. Les Letrados - juristes castillans sous Philippe III. Recherches sur leur place dans la société, la culture et l'état. Poitiers: Pelorson, 1980.

Rao, Cesare. Invettive, Orationi, et Discorsi. Appresso Damiano Zenaro, 1587, https:// reader.digitale-sammlungen.de//de/fsi/object/display/bsb11216694_oooo5.html (Accessed: 31.08.2020).

Romero-Díaz, Nieves. Nueva nobleza, nueva novela: reescribiendo la cultura urbana del barroco. Newark, DE: Juan de la Cuesta, 2002.

Sánchez Jiménez, Antonio. "Los casos de conciencia en la novela pastoril del Siglo de Oro: casuismo y probabilismo en la Arcadia (1598) de Lope de Vega." Revista de literatura 76.151 (2014): 79-100.

Söffner, Jan. "Die Kunst, Novellen in die Welt zu setzen. Zur Fiktionalität in Boccaccios Decameron und Chaucers Canterbury Tales." Giovanni Boccaccio in Europa. Studien zu seiner Rezeption in Spätmittelalter und Früher Neuzeit. Eds. Achim Aurnhammer and Rainer Stillers. Berlin/Boston: De Gruyter, 2014: 277-294.

Stierle, Karlheinz. "Three Moments in the Crisis of Exemplarity: Boccaccio-Petrarch, Montaigne, and Cervantes." Journal of the History of Ideas 59.4 (1998): 581-595.

Suárez de Figueroa, Cristóbal. El pasajero, Ed. Enrique Suárez Figaredo. Lemir 22 (2018): 355-648. https://parnaseo.uv.es/Lemir/Revista/Revista22/Textos/4_El_Pasajero.pdf (Accessed: 03.09.2020).

Suárez de Figueroa, Cristóbal. La constante Amarilis. Valencia, $16 \circ 9$.

Suárez de Figueroa, Cristóbal. Plaza universal de todas ciencias y artes. Parte traducida de Toscano, y parte compuesta por el Doctor Cristóbal Suárez de Figueroa. Ed. Enrique Suárez Figaredo, 2004. http://users.ipfw.edu/jehle/CERVANTE/othertxts/ Suarez_Figaredo_PlazaUniversal.pdf (Accessed: 29.o9.2020).

Timoneda, Joan. El sobremesa y alivio de caminantes. Zaragoza/Medina del Campo, 1563. 